\title{
SURVIVAL OF STOMACH CANCER PATIENTS IN WESTERN KAZAKHSTAN: A REGISTRY-BASED STUDY
}

\author{
${ }^{1}$ A. B. Tulyayeva, ${ }^{1}$ Y. J. Bekmuhamedov, ${ }^{1}$ L. M. Zhamalieva, ${ }^{1}$ Y. M. Iztleuov, \\ ${ }^{1}$ M. A. Aitmagambetova, ${ }^{1}$ D. A. Zholmuhamedova, ${ }^{2}$ G. A. Zhurabekova, ${ }^{1,2,3,4}$ A. M. Grjibovski \\ ${ }^{1}$ West Kazakhstan Marat Ospanov Medical University, Aktobe, Kazakhstan; ${ }^{2} \mathrm{Al}$ Farabi Kazakh National University. \\ Almaty, Kazakhstan; ${ }^{3}$ Northern State Medical University, Arkhangelsk, Russia; ${ }^{N}$ North-Eastern Federal University, \\ Yakutsk, Russia
}

\begin{abstract}
Introduction: Stomach cancer is the fourth most common cancer worldwide. Although there is a lot of international evidence on survival of stomach cancer patients, the data from Central Asia is still scarce.

Aims: To study one- and five-years survival of stomach cancer patients and its correlates in Western Kazakhstan.

Methods: All histologically confirmed cases of stomach cancer (ICD10 code: C16) registered from 2015 to 2019 in the Aktobe region, Western Kazakhstan, were included in a registry-based historical cohort study. One- and five-years survival with $95 \%$ confidence intervals (CI) was calculated by life tables method. Independent associations between survival and its correlates were studied using Cox regression and presented as crude and adjusted hazard ratios (HR).

Results: Altogether, there were 793 new cases of and 587 deaths from stomach cancer in the Aktobe region over the study period. Sixty-five percent of cases were diagnosed at stage III or IV. The overall one- and five-year survival was $33.1 \%$ and $8.4 \%$, respectively. Significant differences in survival functions across categories were observed for cancer stage $(p<0.001)$, morphological type $(p<0.001)$ and ethnic background $(p=0.017)$. After adjustment, only stage and morphological type of tumor remained significantly associated with the out come. Stage III (HR = 2.3, $95 \%$ CI: 1.5-3.6) and stage IV (HR = 4.4, $95 \%$ CI: 2.8-6.9) were associated with shorter survival compared to the reference category. Patients with intestinal type of cancer were more likely to survive longer (HR $=$ $0.7,95 \%$ CI: 0.6-0.8).

Conclusions: High proportion of cases diagnosed at advance stage and low survival warrant urgent measures on both population and institutional levels. Preventive activities, increased awareness of the population and implementation of routine screening should be among the priority actions to improve survival of stomach cancer patients and decrease cancer mortality in Western Kazakhstan.

Key words: stomach cancer, survival, Kazakhstan, Central Asia, Cox regression, cancer registry
\end{abstract}

\section{ВЫЖИВАЕМОСТЬ БОЛЬНЫХ РАКОМ ЖЕЛУДКА В ЗАПАДНОМ КАЗАХСТАНЕ: РЕГИСТРОВОЕ ИССЛЕДОВАНИЕ}

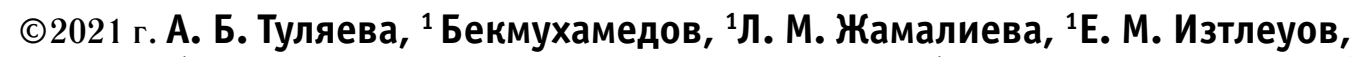
${ }^{1}$ М. А. Айтмагамбетова, ${ }^{1}$ Д. А. Жолмухамедова, ${ }^{2}$ Г. А.Журабекова, ${ }^{1,2,3,4}$ А. М. Гржибовский

1Западно-Казахстанский Медицинский Университет имени Марата Оспанова, г. Актобе, Казахстан; ${ }^{2}$ Казахский Национальный Университет имени Аль-Фараби, г. Алматы, Казахстан; ${ }^{3}$ Северный государственный медицинский университет, г. Архангельск, Россия; ${ }^{4}$ Северо-Восточный федеральный университет, г. Якутск, Россия

Введение. Рак желудка занимает четвертое место по распространенности среди онкологических заболеваний в мире. Несмотря на обилие литературы о выживаемости пациентов с раком желудка, информации о выживаемости и факторах, с ней связанных, в Средней Азии недостаточно.

Цель: оценить одно- и пятилетнюю выживаемость пациентов с раком желудка и связанные с ней факторы в Западном Казахстане. Методы. Все новые гистологически подтвержденные случаи рака желудка (код (16 по МКБ-10) за период 2015-2019 гг., включенные в региональный онкорегистр в Актюбинской области Казахстана, были включены в историческое регистровое когортное исследование. Одно- и пятилетняя выживаемость была рассчитана с помощью таблиц дожития и представлена с $95 \%$ доверительными интервалами (ДИ). Независимые связи между выживаемостью и ассоциированными факторами оценивали с помощью многомерного анализа пропорциональных рисков Кокса и представляли с помощью нескорректированных и скорректированных относительных рисков (ОР).

Результаты. Всего в Актюбинской области в 2015-2019 гг. было зарегистрировано 793 новых случая и 587 летальных исходов от рака желудка. 65 \% случаев имели стадии III или IV при обращении. Одно- и пятилетняя выживаемость составили 33,1 и 8,4 \% соответственно. Значимые различия в выживаемости были выявлены для стадии рака $(p<0,001)$, морфологического типа ( $p<$ $0,001)$ и национальности $(p=0,017)$. В многомерном анализе скорректированные ОР были статистически значимы только для стадии и морфологического типа опухоли. Относительные риски для пациентов с III и IV стадией составили 2,3 (95 \% ДИ: 1,5-3,6) и 4.4 (95\% ДИ: 2,8-6,9) по сравнению с референтной группой. Интестинальный тип был связан с лучшей выживаемостью (ОР = $0,7,95 \%$ ДИ: 0,6-0,8).

Выводы. Большая доля случаев, диагностированных на III-IV стадии, и низкая выживаемость требуют активных мер на популяционном и организационном уровнях. Профилактика, повышение информированности пациентов, а также меры, направленные на раннюю выявляемость рака желудка, должны стать приоритетными задачами для улучшения выживаемости и уменьшения смертности от рака желудка в Западном Казахстане.

Ключевые слова: рак желудка, выживаемость, Казахстан, Средняя Азия, регрессия Кокса, онкологический регистр

For citing:

Tulyayeva A. B., Bekmuhamedov Y. J., Zhamalieva L. M., Iztleuov Y. M., Aitmagambetova M. A., Zholmuhamedova D. A., Zhurabekova G. A., Grjibovski A. M. Survival of Stomach Cancer Patients in Western Kazakhstan: a Registry-Based Study. Ekologiya cheloveka (Human Ecology). 2021, 1, pp. 51-56. 


\section{Библиографическая ссылка:}

Туляева А. Б., Бекмухамедов Е. Ж., Жамалиева Л. М., Изтлеуов Е. М., Айтмагамбетова М. А., Жолмухамедова Д. А., Журабекова Г. А., Гржибовский А. М. Выживаемость больных раком желудка в Западном Казахстане: регистровое исследование // Экология человека. 2021. № 1. С. 51-56.

\section{Introduction}

Stomach cancer is among the most common cancers. More than a million new cases and 783,000 deaths are registered worldwide every year. It is the fourth most frequently diagnosed cancer and the third leading cause of death from cancer [10]. As for many other cancers, more than $70 \%$ of cases of stomach cancer occur in developing countries and $50 \%$ occur in Asia. The incidence of gastric cancer is high and increasing in most Asian countries, while the opposite has been reported from North America, Northern Europe and some African settings [2].

Stomach cancer is a multifactorial disease with both genetic and environmental components. Advanced age, male gender, obesity, smoking, family history, excessive salt consumption, Helicobacter pylori infection and gastroesophageal reflux disease have been shown to be associated with stomach cancer [14]. More information about genetic predisposition, risk factors and pathophysiology of stomach cancer is presented elsewhere $[4,6-9,24]$

Several classifications of gastric cancer have been proposed. Borrmann [1], WHO [27], Ming [26] and Lauren [20] classifications are among the most common in the literature. The latter seems to be the most frequently used in epidemiological studies on survival [22, 25, 29, 33].

In Kazakhstan, the overall incidence of gastric cancer in 2018 was 9.2 per 100,000 people making it the third most common cancer in the country after breast cancer and lung cancer, and the second most common cause of cancer death. The incidence of gastric cancer among men (12.5 per 100,000$)$ is double as high as among women (6.2 per 100,000) [11]. However, Kazakhstan is a large country with significant East-West and NorthSouth economic, ethnic, cultural and health differences. Given that national data may mask regional variation, studies on regional level are warranted.

Cancer registries with high coverage and completeness are a gold mine for epidemiological research not only in developed but also in developing countries [5]. Several regional cancer registries have been established in Kazakhstan in the 2000s providing opportunities for both research and monitoring.

The aim of this study was to assess one- and fiveyears survival of patients with gastric cancer in West Kazakhstan as well as to provide quantitative estimates of the associations between selected factors influencing survival of gastric patients using a regional populationbased cancer registry.

\section{Methods}

This is a registry-based historical cohort study. All histologically confirmed cases of gastric cancer (ICD10 code: C16) registered from 1 January 2015 to 31 December 2019 in the Aktobe region, West Kazakhstan, comprised the study base. The main source of data was a regional electronic cancer registry which covers virtu- ally all cancer cases in the Aktobe region. Cases with stomach cancer diagnosed only at autopsy were excluded.

For the purpose of this paper we extracted information on date of birth, date of diagnosis of stomach cancer, date of death or censoring, place of residence, ethnic background, morphological type of tumor by Lauren [20] and stage of cancer. All cases were followed up until death or 31 December 2019 whichever occurred first.

Age at the time of diagnosis was calculated using date of birth and date of diagnosis and was classified as 18 49, 50-59 and 60+ years. By ethnicity all patients were dichotomized into Kazakhs and others. The overwhelming majority among the others were ethnic Russians. Place of residence was dichotomized into urban and rural. By morphological type the following categories were used: diffuse, intestinal and mixed. The stage of stomach cancer was based on the classification of the American Joint Committee on Cancer TNM classification, 7th edition and coded from I to IV. By localization, the cancers were dichotomized into cardia- and other parts of the stomach cancer (non-cardia cancers). What is considered the most favorable category was selected as the reference group.

One- and five-years survival with $95 \%$ confidence intervals (CI) was calculated by life tables method across independent variables and compared using WilcoxonGehan tests. Survival functions were plotted using Kaplan-Maier curves and compared across independent variables by log-rank tests. Independent associations between potential predictors and survival were studied using Cox regression. Crude and adjusted hazard ratios (HR) were calculated with $95 \%$ CI.

The study was approved be the local ethical committee at the West Kazakhstan Marat Ospanov Medical University (Protocol \#24 from 3 October 2017).

\section{Results}

Altogether, there were 793 new cases of and 587 deaths from gastric cancer in the Aktobe region over the study period. Of them, only $5.0 \%$ were diagnosed at the stage I cancer while $64.7 \%$ were diagnosed at the stages III or IV. Patient's characteristics and pathological features of the tumors are summarized in Table 1.

The overall one-year and five-year survival was $33.1 \%$ and $8.4 \%$, respectively. Significant differences in survival measured using life-tables were observed by stage $(p<0.001)$, morphological type of the tumor $(p$ $<0.001)$ and ethnic background $(\mathrm{p}=0.036)$. Ethnic Kazakhs were more likely to survive longer than patients belonging to other ethnic groups. Detailed information about one- and five-years survival across all studied variables is presented in Table 1 .

Kaplan-Meier survival curves for each of the selected factors are presented in Figure 1. Significant differences in survival functions across categories were observed for cancer stage $(p<0.001)$, morphological type $(p<$ $0.001)$ and ethnic background $(p=0.017)$.

After adjustment for all factors included in this study, 
One- and five-years survival of gastric cancer patients in 2015-2019 in the Aktobe region (Western Kazakhstan) with $95 \%$ confidence intervals $(\mathrm{CI})$

\begin{tabular}{|c|c|c|c|c|c|c|c|c|c|c|}
\hline Variable & $\begin{array}{c}\mathrm{N} \text { of new } \\
\text { cases }\end{array}$ & $\%$ & $\mathrm{~N}$ deaths & $\%$ & $\begin{array}{c}\text { One-year } \\
\text { survival }\end{array}$ & $95 \% \mathrm{CI}$ & $\begin{array}{c}\text { Five-years } \\
\text { survival }\end{array}$ & $95 \% \mathrm{CI}$ & $\begin{array}{c}\text { Median } \\
\text { survival, } \\
\text { months }\end{array}$ & $\mathrm{p}^{*}$ \\
\hline Age, years & & & & & & & & & & 0.842 \\
\hline $18-49$ & 108 & 13.6 & 73 & 12.4 & 0.34 & $0.24-0.44$ & 0.16 & $0.06-0.26$ & 9.05 & \\
\hline $50-59$ & 189 & 12.8 & 136 & 23.2 & 0.37 & $0.29-0.46$ & 0.11 & $0.05-0.17$ & 9.46 & \\
\hline $60+$ & 496 & 62.6 & 378 & 64.4 & 0.32 & $0.28-0.36$ & 0.06 & $0.02-0.10$ & 8.78 & \\
\hline Gender & & & & & & & & & & 0.159 \\
\hline Female & 277 & 34.9 & 218 & 37.1 & 0.28 & $0.22-0.34$ & 0.08 & $0.04-0.12$ & 8.37 & \\
\hline Male & 516 & 65.1 & 369 & 62.9 & 0.36 & $0.32-0.40$ & 0.09 & 0.05-0.13 & 9.33 & \\
\hline Ethnicity & & & & & & & & & & 0.036 \\
\hline Kazakh & 651 & 82.1 & 470 & 80.0 & 0.35 & $0.31-0.39$ & 0.10 & $0.06-0.14$ & 9.18 & \\
\hline Other & 142 & 17.9 & 117 & 20.0 & 0.26 & $0.18-0.34$ & 0.04 & $0.00-0.08$ & 8.14 & \\
\hline Place of residence & & & & & & & & & & 0.171 \\
\hline Urban & 441 & 55.6 & 317 & 54.0 & 0.35 & $0.31-0.39$ & 0.09 & $0.05-0.13$ & 9.29 & \\
\hline Rural & 351 & 44.4 & 270 & 46.0 & 0.30 & $0.26-0.34$ & 0.08 & $0.02-0.14$ & 8.61 & \\
\hline Stage & & & & & & & & & & $<0.001$ \\
\hline $\mathrm{I}$ & 40 & 5.0 & 23 & 3.9 & 0.65 & $0.49-0.81$ & 0.11 & $0.00-0.25$ & 19.1 & \\
\hline II & 240 & 30.3 & 133 & 22.7 & 0.65 & $0.59-0.71$ & 0.16 & $0.08-0.22$ & 18.3 & \\
\hline III & 330 & 41.6 & 260 & 44.3 & 0.22 & $0.18-0.26$ & 0.07 & $0.03-0.11$ & 7.73 & \\
\hline IV & 183 & 23.1 & 171 & 29.1 & 0.08 & $0.04-0.12$ & 0.02 & $0.00-0.06$ & 6.49 & \\
\hline Tumor location & & & & & & & & & & 0.858 \\
\hline Cardia & 344 & 43.4 & 251 & 42.8 & 0.33 & $0.27-0.39$ & 0.12 & $0.06-0.18$ & 8.99 & \\
\hline Non-cardia & 449 & 56.6 & 336 & 57.2 & 0.33 & $0.29-0.37$ & 0.07 & $0.03-0.11$ & 8.96 & \\
\hline Morphological type & & & & & & & & & & $<0.001$ \\
\hline Diffuse & 349 & 44.0 & 292 & 49.7 & 0.19 & $0.15-0.23$ & 0.06 & $0.02-0.10$ & 7.42 & \\
\hline Intestinal & 417 & 52.6 & 280 & 47.7 & 0.45 & $0.39-0.51$ & 0.10 & $0.06-0.14$ & 10.8 & \\
\hline Mixed & 27 & 3.4 & 15 & 2.6 & 0.43 & $0.23-0.63$ & - & - & 10.5 & \\
\hline Total & 793 & 100.0 & 587 & 100.0 & 0.33 & $0.29-0.37$ & 0.08 & $0.04-0.12$ & 8.97 & \\
\hline
\end{tabular}

Table 2

Crude and adjusted hazard ratios (HR) with $95 \%$ confidence intervals (CI) for the associations between selected factors and survival of gastric cancer patients in 2015-2019 in the Aktobe region (Western Kazakhstan)

\begin{tabular}{|c|c|c|c|c|c|c|}
\hline Variable & Crude HR & $95 \% \mathrm{CI}$ & $\mathrm{p}$ & Adjusted HR & $95 \% \mathrm{CI}$ & $\mathrm{p}$ \\
\hline Age. years & & & 0.196 & & & 0.301 \\
\hline $18-49$ & 1.00 & Reference & & 1.00 & Reference & \\
\hline $50-59$ & 0.96 & $0.72-1.28$ & & 1.23 & $0.92-1.65$ & \\
\hline $60+$ & 1.14 & $0.88-1.49$ & & 1.21 & $0.94-1.55$ & \\
\hline Gender & & & 0.074 & & & 0.121 \\
\hline Female & 1.00 & Reference & & 1.00 & Reference & \\
\hline Male & 0.86 & $0.73-1.02$ & & 0.88 & $0.74-1.04$ & \\
\hline Ethnicity & & & 0.024 & & & 0.418 \\
\hline Kazakh & 1.00 & Reference & & 1.00 & Reference & \\
\hline Other & 1.24 & $1.03-1.55$ & & 1.09 & $0.89-1.34$ & \\
\hline Place of residence & & & 0.109 & & & 0.127 \\
\hline Urban & 1.00 & Reference & & 1.00 & Reference & \\
\hline Rural & 1.14 & $0.97-1.34$ & & 1.14 & $0.96-1.34$ & \\
\hline Stage & & & $<0.001$ & & & $<0.001$ \\
\hline $\mathrm{I}$ & 1.00 & Reference & & 1.00 & Reference & \\
\hline II & 0.86 & $0.57-1.39$ & & 0.88 & 0.56-1.38 & \\
\hline III & 2.40 & $1.56-3.68$ & & 2.33 & $1.51-3.61$ & \\
\hline IV & 4.84 & $2.98-7.21$ & & 4.43 & $2.82-6.94$ & \\
\hline Tumor location & & & 0.767 & & & 0.255 \\
\hline Cardia & 1.00 & Reference & & 1.00 & Reference & \\
\hline Non-cardia & 1.03 & $0.87-1.21$ & & 1.10 & $0.93-1.30$ & \\
\hline Morphological type & & & $<0.001$ & & & $<0.001$ \\
\hline Diffuse & 1.00 & Reference & & 1.00 & Reference & \\
\hline Intestinal & 0.60 & $0.51-0.71$ & & 0.71 & $0.60-0.84$ & \\
\hline Mixed & 0.59 & $0.35-0.99$ & & 0.65 & $0.39-1.10$ & \\
\hline
\end{tabular}



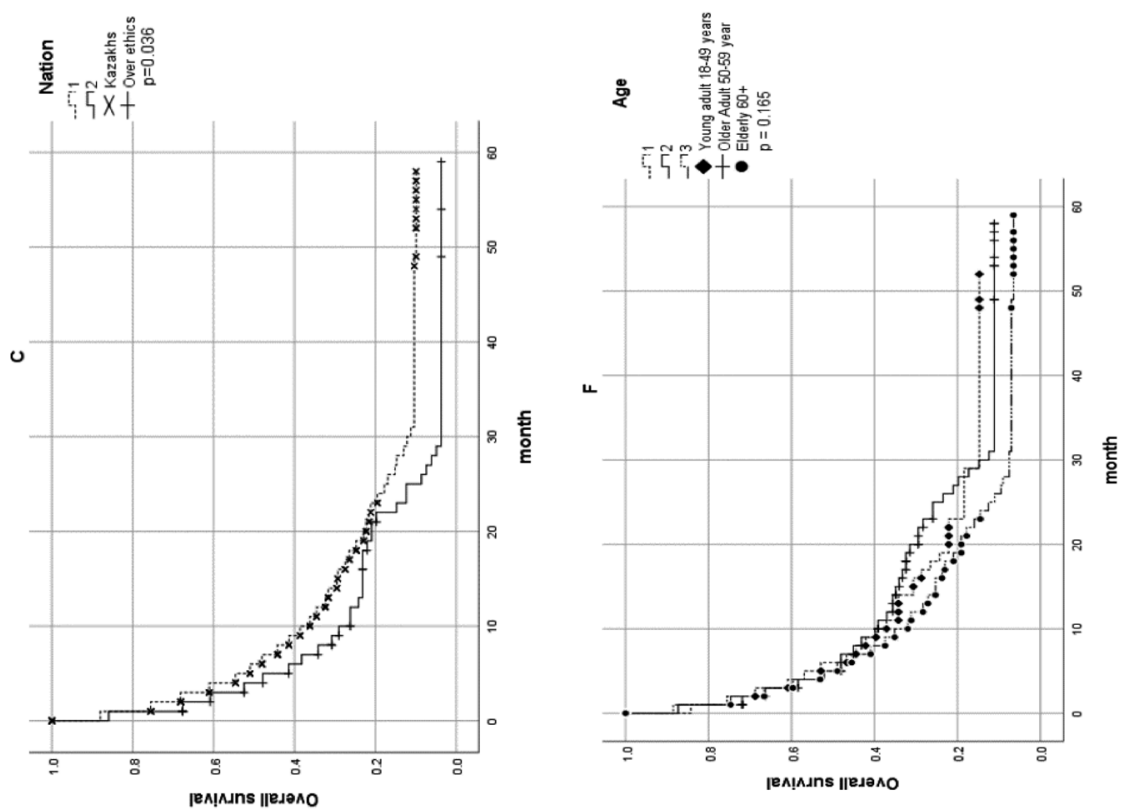

(1)
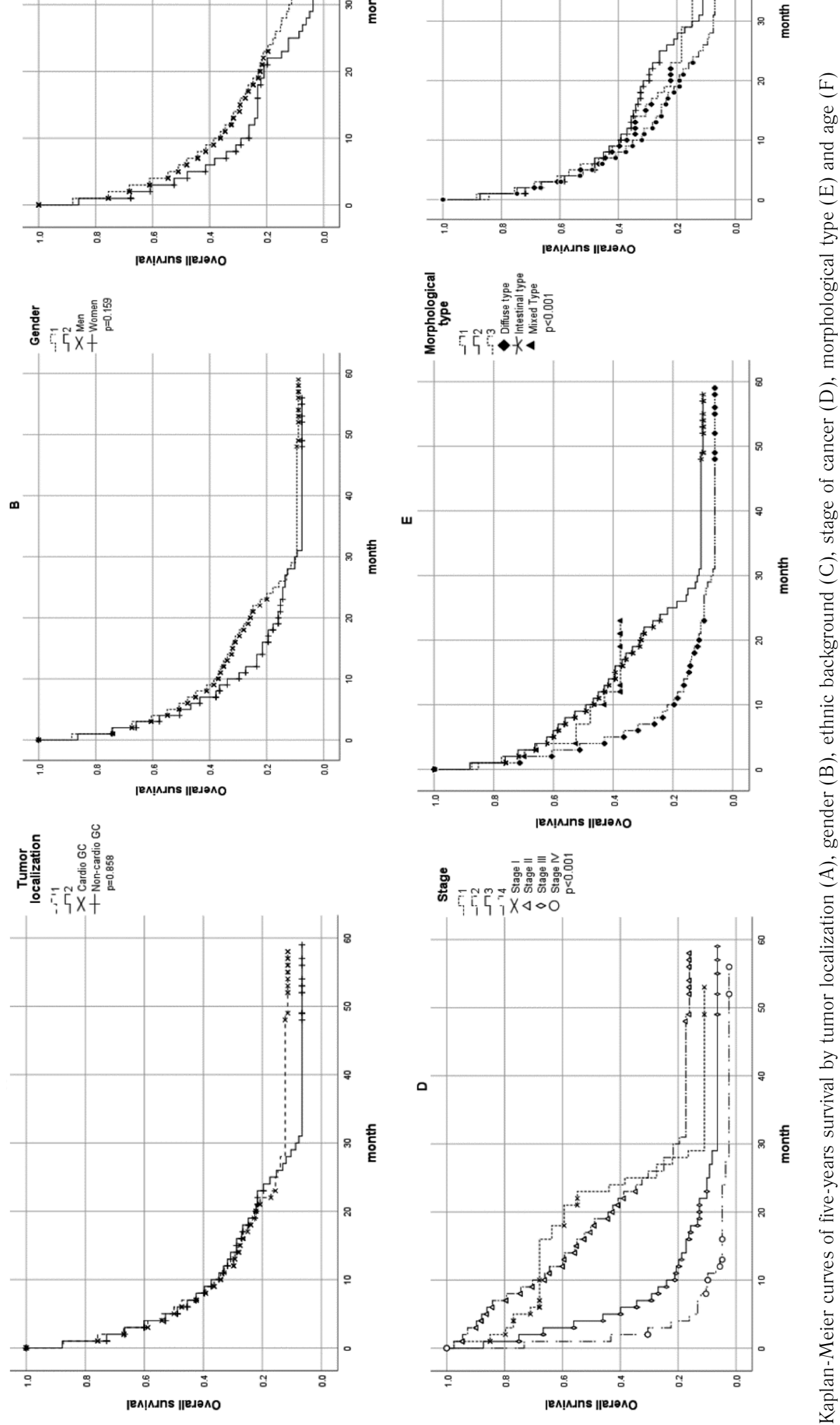
only stage and morphological type of tumor remained significantly associated with survival (Table 2). Stage III $(\mathrm{HR}=2.3,95 \% \mathrm{CI}: 1.5-3.6)$ and stage IV (HR $=4.4,95 \%$ CI: 2.8-6.9) were associated with shorter survival compared to the reference category. Patients with intestinal type of stomach cancer were more likely to survive longer ( $\mathrm{HR}=0.7,95 \% \mathrm{CI}$ : 0.6-0.8). Mixed type of cancer was also associated with better survival, but the results have not reached statistical significance.

\section{Discussion}

This study is among the first studies from Kazakhstan assessing survival and associated factors using data from regional cancer registries. The main findings suggest that both one- and five-years survival of stomach cancer patients in the Aktobe region is considerably lower than in most other countries of the European WHO region which can be at least partly explained by the fact that only $5 \%$ of cases were diagnosed at stage 1 while $64.7 \%$ of cases were diagnosed at advanced stages of the disease. At the same time, the factors associated with survival, namely, stage and morphological type are in line with the international evidence.

Although male gender is often considered as a risk factor for stomach cancer for several reasons and that almost two thirds of cases in our study were men, we have not observed differences in survival between genders. Moreover, men tended to have better oneyear and median survival compared to women in our study, although the results have not reached the level of statistical significance.

Advanced age is known to be associated with greater probability to develop cancer. Some studies have shown poorer survival in young patients [15, 21,23] while other studies have reported comparable survival of patients form different age groups [12, 28, 30-33]. In our study there was no association between survival and age at diagnosis in either crude or adjusted analysis.

Urban residents have slightly better survival not reaching the level of significance compared to their rural counterparts. One could hypothesize that rural residence may be associated with greater probability of late detection of cancers. However, adjustment for stage at diagnosis have not influenced the hazard ratio indications that both urban and rural residents contact medical facilities similarly late.

Ethnic Kazakhs had longer median survival and were more likely to live longer than patients of other ethnicities. One may speculate that stronger family ties and better support to the patients in Kazakh families may contribute to this finding. However, the HR in multivariable survival analysis was substantially reduced after adjustment for the other studied variables and the association lost its statistical significance. This means that the factors included in Table 2 can explain the initial differences in survival between ethnic groups.

Similarly to most other studies, we found an inverse association between survival and stage of cancer at the time of diagnosis. The stage at which the disease is detected plays an important role in treatment selection, which in turn influences the survival $[3,17,18]$. Interestingly, one-year survival of patients with stage II was similar to that in the most favorable group, but five-years survival was $16 \%$ compared to the $11 \%$ in the reference group. However, wide confidence intervals indicate that these point estimates are not statistically different.

Earlier studies have reported differences in survival between cardia and non-cardia cancers [13] while other authors suggested no difference if a stage is taken into account [18]. We found no differences in survival by tumor localization in either crude or adjusted analysis with harard ratios being close to unity.

We found that patients with intestinal type of cancer had better survival. Intestinal-type cancers occur as a result of chronic atrophic gastritis and subsequent intestinal metaplasia and are associated predominantly with chronic Helicobacter pylori infection [16, 19].

Although the main advantage of this study is the use of the regional cancer registry covering virtually all cases of stomach cancer in the region, the results of the study should be interpreted with caution taking into account its limitations. We cannot generalize our findings to other settings of Kazakhstan due to substantial heterogeneity of the regions. Moreover, although we included all cases from the registry, the size of the study is fairly small to detect small and moderate effects. At the same time, we were able to detect significant hazard ratios of 2.3 or greater. The number of variables is also limited. However, our findings on no differences across genders, place of residence and ethnic background may reflect low level of inequalities in terms of availability and affordability of medical services to all residents of Western Kazakhstan.

Given that a new national electronic cancer registry has been recently established in Kazakhstan further research should use the data from that registry to ensure sufficient number of cases to detect moderate and minor associations between survival and associated factors.

Given that the incidence of stomach cancer in Western Kazakhstan and in Kazakhstan in general is high, one should consider development of a screening program to increase the proportion of cases detected at an early stage since the treatment is available. Although screening programs for stomach cancer have not been recommended in countries with low incidence [14], they may be relevant for Kazakhstan. In addition, our observation on that almost two thirds of cases approach medical facilities at an advanced stage may indicate low cancer awareness in the region and poor prevention of stomach cancer.

To conclude, high proportion of cases diagnosed at advance stage and low survival warrant urgent measures on both population and institutional levels. Preventive activities, increased awareness of the population and implementation of stomach cancer screening should be among the priority actions to improve survival of stomach cancer patients and decrease cancer mortality in Western Kazakhstan.

\section{Acknowledgements}

We thank Valery Begunov from the Aktobe Regional Cancer Registry for his assistance in data acquisition and Dr Kerbez Kimatova for English language review.

\section{Authors' contribution:}

Tulyayeva A. B., Bekmuhamedov Y. J., Grjibovski A. M. and Iztleuov Y. M. conceived the study; Tulyayeva A. B., Aitmagambetova M. A., Zholmuhamedova D. A. acquired the data; Grjibovski A. M. and Tulyayeva A. B. contributed 
to the data analysis; Smagulova G.A., Grjibovski A. M. and Balmagambetova S. K. drafted the manuscript. All authors contributed to critical evaluation and revisions of the repeated versions of the manuscript. All authors approved the final version of the paper.

Tulyaeva A. B. - ORCID 0000-0001-7149-0121

Bekmuhamedov Y. J. - ORCID 0000-0001-8610-8140

Iztleuov Y. M. - ORCID 0000-0002-5303-8593

Balmagambetova S. K. - ORCID 0000-0003-4080-5383

Smagulova G. A. - ORCID 0000-0001-7222-620x

Aitmagambetova M. A. - ORCID 0000-0002-0346-5829

Zholmuhamedova D. A. - ORCID 0000-0002-3899-2856

Grjibovski A. M. - ORCID 0000-0002-5464-0498

\section{References}

1. Borrmann R. Geschwülste des Magens und Duodenums In Handbuch des Speziellen Pathologischen Anatomie und Histologie. Henke F., Lubarsch O., eds. Springer, Berlin, Germany, 1926.

2. Bray F., Ferlay J., Soerjomataram I., Siegel R. L., Torre L. A., and Jemal A. Global cancer statistics 2018: GLOBOCAN estimates of incidence and mortality worldwide for 36 cancers in 185 countries. CA: Cancer Journal for Clinicians. 2018, 68 (6), pp. 394-424.

3. Carboni F., Lepiane P., Santoro R., Lorusso R., Mancini P., Sperduti I., et al..Extended multiorgan resection for T4 gastric carcinoma: 25-year experience. J Surg Oncol. 2005, 90 (2), pp. 95-100.

4. Chen Y. C., Fang W. L., Wang R. F., et al. Clinicopathological Variation of Lauren Classification in Gastric Cancer. Pathol Oncol Res. 2016, 22 (1), pp. 197-202.

5. Correa P., Bolanos O., Garcia F., Gordillo G., Duque E., Cuello C. The Cancer Registry of Cali, Colombia. Epidemiologic studies of gastric cancer. Recent Results in Cancer Research. 1975, 50, pp. 155-169.

6. Correa P., Cuello C., Duque E., Burbano L. C., Garcia F. T., Bolaños O., et al. Gastric cancer in Colombia. III Natural history of precursor lesions. J Natl Cancer Inst. 1976 , 57, pp. 1027-35.

7. Correa P., Cuello C., Duque E. Carcinoma and intestinal metaplasia of the stomach in Colombian migrants. J Natl Cancer Inst. 1970, 44, pp. 297-306.

8. Correa P. Gastric cancer: overview. Gastroenterol Clin North Am. 2013, 42 (2), pp. 211-217.

9. Corso G., Marrelli D., and Roviello F. Familial gastric cancer and germline mutations of E-cadherin. Ann Ital Chir. 2012, 83, pp. 177-182

10. Ferlay J., Ervik M., Lam F., Colombet M., Mery L., Piñeros M., Znaor A, Soerjomataram I, Bray F. Global Cancer Observatory: Cancer Today. Lyon, France: International Agency for Research on Cancer, 2018. Available from: http:// gco.iarc.fr/today/data/factsheets/cancers/7-Stomach-factsheet.pdf (accessed: 10 April 2020)

11. Ferlay J., Ervik M., Lam F., Colombet M., Mery L., Piñeros M., Znaor A., Soerjomataram I., Bray F. Global Cancer Observatory: Cancer Today. Lyon, France: International Agency for Research on Cancer, 2018. Available from: http://gco.iarc.fr/today/data/factsheets/populations/398kazakhstan-fact-sheets.pdf (accessed: 10 April 2020).

12. Isobe T., Hashimoto K., Kizaki J. et al. Characteristics and prognosis of gastric cancer in young patients. Oncol Rep. 2013, 30, pp. 43-49.

13. Kim D. Y., Joo J. K., Ryu S. Y., Park Y. K., Kim Y. .J, Kim S. K. Clinicopathological characteristics and prognosis of carcinoma of the gastric cardia. Dig Surg. 2006, 23 (5-6), pp. 313-318.

14. Kim G. H., Liang P. S., Bang S. J., Hwang J. H. Screening and surveillance for gastric cancer in the United States: Is it needed? Gastrointest Endosc. 2016, 84 (1), pp. 18-28.

15. Kim J. H., Boo Y. J., Park J. M., et al. Incidence and long-term outcome of young patients with gastric carcinoma according to sex: does hormonal status affect prognosis? Arch Surg. 2008, 143, pp. 1062-1067.

16. Kim S. S., Ruiz V. E., Carroll J. D., Moss S. F. Helicobacter pylori in the pathogenesis of gastric cancer and gastric lymphoma. Cancer Lett. 2011, 305, pp. 228-238.

17. Kunisaki C., Akiyama H., Nomura M., Matsuda G., Otsuka Y., Ono H., et al. Surgical outcomes for early gastric cancer in the upper third of the stomach. J Am Coll Surg. 2005, 200 (1), pp. 15-19.

18. Kunisaki C., Akiyama H., Nomura M., Matsuda G., Otsuka Y., Ono H. A., et al. Surgical outcomes in patients with T4 gastric carcinoma. J Am Coll Surg. 2006, 202 (2), pp. $223-230$

19. Lahner Edith \& Carabotti Marilia \& Annibale Bruno. Treatment of Helicobacter pylori infection in atrophic gastritis. World Journal of Gastroenterology. 2018, 24, pp. 2373-2380.

20. Laurén P. The two histological main types of gastric carcinoma: Diffuse and so-called intestinal-type carcinoma. APMIS 6: 209-222. Acta Pathol. Microbiol. Scand. 1965, 6, pp. 31-49.

21. Llanos O., Butte J. M., Crovari F., Duarte I., Guzmán S. Survival of young patients after gastrectomy for gastric cancer. World J Surg. 2006, 30, pp. 17-20.

22. Ma J., Shen H., Kapesa L., Zeng S. Lauren classification and individualized chemotherapy in gastric cancer. Oncol Lett. 2016, 11 (5), pp. 2959-2964.

23. Maconi G., Kurihara H., Panizzo V., et al. Gastric cancer in young patients with no alarm symptoms: focus on delay in diagnosis, stage of neoplasm and survival. Scand $J$ Gastroenterol. 2003, 38, pp. 1249-1255.

24. Marshall B. J., Warren J. R. Unidentified curved bacillus on gastric epithelium in active chronic gastritis. Lancet Oncol. 1983, 1, pp. 1273-1275.

25. Min L., Zhao Y., Zhu S., Qiu X., Cheng R., Xing J., Shao L., Guo S., Zhang S. Integrated analysis identifies molecular signatures and specific prognostic factors for different gastric cancer subtypes. Transl Oncol. 2017, 10, pp. 99-107.

26. Ming S. C. Gastric carcinoma. A pathobiological classification. Cancer. 1977, 39, pp. 2475-2485.

27. Oota K., Sobin L. H. Histological typing of gastric and oesophageal tumours. In International Histological Classification of Tumours. WHO: Geneva, Switzerland, 1977, 46 p.

28. Park J. C., Lee Y. C., Kim J. H., et al. Clinicopathological aspects and prognostic value with respect to age: an analysis of 3,362 consecutive gastric cancer patients. J Surg Oncol. 2009, 99, pp. 395-401.

29. Qiu M. Z., Cai M. Y., Zhang D. S., Wang Z. Q., Wang D. S., Li Y. H., Xu R. H. Clinicopathological characteristics and prognostic analysis of Lauren classification in gastric adenocarcinoma in China. J Transl Med. 2013, 11, p. 58.

30. Ramos-De la Medina A., Salgado-Nesme N., TorresVil-lalobos G., Medina-Franco H. Clinicopathologic characteristics of gastric cancer in a young patient population. J Gastrointest Surg. 2004, 8, pp. 240-244.

31. Simsa J., Leffler J., Hoch J., Linke Z., Pádr R. Gastric cancer in young patients - is there any hope for them? Acta Chir Belg. 2004, 104, pp. 673-676.

32. Takatsu Y., Hiki N., Nunobe S., et al. Clinicopathological features of gastric cancer in young patients. Gastric Cancer. 2016, 19, pp. 472-478.

33. Zheng H., Takahashi H., Murai Y., Cui Z., Nomoto K., Miwa S., Tsuneyama K., Takano Y. Pathobiological characteristics of intestinal and diffuse-type gastric carcinoma in Japan: An immunostaining study on the tissue microarray. J Clin Pathol. 2007, 60, pp. 273-277.

\section{Contact details:}

Anar B. Tulyayeva - MD, PhD candidate at the Department of Oncology, West Kazakhstan Marat Ospanov Medical University, 68 Maresyev St., Aktobe 030019, Kazakhstan

E-mail: dekart_85@mail.ru 